\title{
A POESIA Do TESTEMUNHO E O TESTEMUNhO Da poesia em Primo levi e Varlam Chalámov
}

\author{
The Poetry of Testimony and the Testimony of Poetry \\ in Primo Levi and Varlam Chalámov
}

\author{
Marcelo Ferraz de Paula \\ Universidade Federal de Goiás. Goiânia, GO, Brasil. \\ Pesquisador CNPq - E-mail: marcelo2867@ufg.br
}

EDITORES:

Regina Zilberman

Gerson Roberto Neumann

SUBMETIDO: 07.12 .2020

ACEITO: 01.02.2021

\section{COMO CITAR:}

PAULA, Marcelo Ferraz de. A poesia do testemunho e o testemunho da poesia em Primo Levi e Varlam Chalámov. Revista Brasileira de Literatura Comparada, v. 23 , n. 43 , p. $80-93$, mai.ago., 2021. doi: https:// doi.org/10.1590/2596304x20212343mfp http:// www.scielo.br/rblc https://revista.abralic.org.br

\section{RESUMO}

Este ensaio visa compartilhar algumas reflexões sobre o binômio poesia e catástrofe, tecidas a partir da leitura de passagens das obras testemunhais de Primo Levi e Varlam Chalámov. Coloca-se em questão quais os (não) sentidos possíveis para a criação artística em contextos de violência extrema, como os Campos de Concentração nazistas e os Gulags soviéticos onde, respectivamente, estiveram presos os dois autores.

Palavras-chave: Testemunho, poesia, Primo Levi, Varlam Chalámov.

\section{Abstract}

The essay objectives to share some reflections about poetry and catastrophe, with focus on the reading of passages from the testimonial works of Primo Levi and Varlam Chalámov. We discuss the (non)possible meanings for artistic creation in contexts of extreme violence, such as the Nazi Concentration Camps and the Soviet Gulags where, respectively, the two authors were imprisoned.

KeYwords: Testimony, poetry, Primo Levi, Varlam Chalámov.

relação entre poesia e catástrofe é historicamente marcada por
um profundo paradoxo. Por um lado, observamos uma limitação
da linguagem poética para lidar com certas situações extremas de terror, diante das quais a sua conversão em objeto estético soa como vã ou mesmo indecorosa. Por outro lado, a produção e a evocação da poesia em contextos de violência extrema é recorrente em todas as línguas modernas, em todos os tempos históricos, constituindo uma importante fonte de reflexão ética sobre a barbárie. Este impasse ganhou notoriedade no século XX, com suas guerras, genocídios e ditaduras, que nos legou simultaneamente uma vasta produção poética vinculada a experiências degradantes, como a prisão, o exílio, a tortura. No terreno da linguagem poética se materializa, portanto, uma aporia que está por trás de todo esforço de representação artística de eventos catastróficos: "ter que equacionar o infinito da violência, em si desmedida e sem forma, com o finito da escrita, de uma forma literária ou cultural” (VECCHI, 2017, p. 179). 
Muito já foi dito sobre a simultânea urgência e insuficiência da linguagem para abarcar o impacto traumático, seja na perspectiva pessoal dos sobreviventes, seja em seus ecos na cultura contemporânea. Toda uma linhagem de obras testemunhais se consolidou tentando evitar o risco da estetização do horror, ao mesmo tempo em que se confrontavam com a impossibilidade de uma literalização absoluta da catástrofe, devido ao seu caráter traumático. De tal modo que as vítimas "sentem uma ânsia desenfreada de comunicar, de falar, de contar, de escrever e, ao mesmo tempo, têm a nítida percepção da vaidade desse empreendimento narrativo, porque ele é incapaz de realmente dizer o horror" (GAGNEBIN, 2000, p. 107, grifo da autora).

Apesar de ser menos estudada no âmbito dos estudos sobre o testemunho, a poesia tem sido uma forma crucial de manifestação do trauma e da barbárie históricos, não escapando, portanto, desse paradoxo. Ao contrário, na poesia - devido ao esvaziamento de sua origem ritualística, na modernidade, bem como pela sua cristalização cultural como uma arte relativamente autônoma e primordialmente estética - a tensão entre a "utilidade" e o sentido de se escrever poesia sobre ou em contexto de opressão atinge uma dramaticidade acentuada. Isso porque a catástrofe seria, de certo modo, a antítese da poesia, o limiar que a esvazia e não aceita ser tocado por ela sem que ela deixe de ser aquilo que é. De maneira radical, Adorno (1998) enfrentou esse impasse em um de seus aforismos mais conhecidos e controversos, ao afirmar que seria impossível escrever poesia após Auschwitz. Depois do horror extremo, o silêncio e a dissolução. Depois de Auschwitz, apenas o poema impossível, rompendo com qualquer ilusão beletrista ou edificante, poderia emergir sem ser parte da barbárie.

Não obstante, a história literária faz questão de nos lembrar que, a cada nova hecatombe, tão forte como o anseio de recalque é a necessidade imperativa de mediação simbólica através da linguagem poética. O sofrimento atravessa a poesia de todos os tempos; os mais lancinantes períodos históricos não são épocas de silêncio decoroso ou desistência envergonhada dos poetas, mas de ebulição artística. Essa dualidade está latente desde os momentos fundantes da arte ocidental, conforme explicita Márcio Seligmann-Silva:
A arte, segundo uma certa concepção clássica, é o campo da fruição do belo e, segundo uma certa tradição clássica ainda, a arte seria um meio de ensinar o "bem”. Poder-se-ia perguntar, então, se seria possível uma conciliação entre a arte "da dor" e essa visão tradicional da arte? Ora, na verdade isso não só é possível, como também, de certo modo, essa modalidade da arte sempre foi no mínimo tão importante - e "clássica" - quanto a sua face avessa à representação da dor. (SELIGMANN-SILVA, 2003, p. 29)

Portanto, é preciso ter em mente que a concepção harmônica da arte, criando objetos deleitáveis e orgânicos, sempre conviveu com uma dimensão dolorosa, mutilada e indigesta da existência humana, a qual nunca deixou de representar o sofrimento mais terrificante. A poesia não move o pau de arara, como afirmou o poeta Ferreira Gullar (2010), mas tem, a cada nova ascensão autoritária, desenvolvido estratégias formais de resistência, ao mesmo tempo em que constitui uma abrangente memória cultural de períodos plúmbeos da história.

Assim, mesmo nos sistemas de opressão mais implacáveis, como as indústrias da morte engendradas pela Alemanha nazista, encontramos inúmeros registros de expressão artística e poética. Seus propósitos poderiam ser grandiosos e coletivos: denunciar, unir, resistir; ou mais singelos, como consolar, distrair, expressar uma dor profunda ou deixar um diminuto vestígio de uma vida obstruída pelo terror. Uma ínfima parte dessa produção chegou até nós, compondo um testemunho complexo e 
arrebatador desses eventos e, sob nenhum ângulo, inclusive o do utilitarismo mais pragmático, poderia ser considerada "inútil”.

O campo de Theresienstadt, na atual República Checa, legou exemplos substanciais dessa persistência da arte em um meio extremamente hostil. Por ser utilizado nas propagandas de Hitler com o intuito de apresentar às potências mundiais uma imagem palatável dos campos de concentração, ocasionalmente o lugar passava por uma maquiagem de sua estrutura física. Os prisioneiros eram bem alimentados e atividades culturais organizadas pelos judeus eram toleradas, ou mesmo incentivadas ${ }^{1}$. Ali foram aprisionados inúmeros judeus proeminentes, incluindo importantes artistas, e, conforme Ecléa Bosi:

Terezin concentrou em si uma terrível beleza. A resistência à "banalidade do mal" se apresentou em formas expressivas na música, na pintura, no teatro, na poesia... A concentração rara de talentos, rara na história da cultura ocidental, servirá aos nazistas de propaganda. Mas também houve uma arte subterrânea, de denúncia. À noite, os prisioneiros improvisam pequenas peças clandestinas em diferentes línguas. [...] Criava-se uma atmosfera mágica de compreensão, Babel ao reverso. (BOSI, 2004, p. 95)

Em outro polo dessa relação podemos pensar num exemplo oposto, com o intuito de sublinhar a complexidade da presença da arte nos campos de concentração. Mesmo nos campos em território polonês havia pequenas orquestras, nas quais os prisioneiros eram obrigados a tocar sob a ordem dos algozes nazistas, gerando uma relação perversa da arte em meio à catástrofe. Neste caso, a arte obviamente não estava ligada à resistência ou subjetivação dos prisioneiros, mas a uma espécie nova de castigo, cruel e humilhante, que ficaria marcado na memória de muitos sobreviventes, dentre eles no grande poeta Paul Celan, que eternizou essa zona obscura da vivência artística em seu mais famoso poema, "Todefuge".

Testemunhas atentas do horror, o escritor italiano Primo Levi e o autor russo Varlam Chalámov compartilham, além de suas obras fundamentais para a compreensão dos estados totalitários modernos, a condição de sobreviventes de duas das maiores tragédias do último século: o genocídio de judeus e outros grupos étnicos e sociais nos Campos de Concentração nazistas e o massacre de prisioneiros nos Gulags soviéticos. São duas vozes fundamentais da chamada "literatura de testemunho", a de Levi já consagrada internacionalmente há algum tempo e a de Chalámov num lento, mas vigoroso, processo de (re)descobrimento e valorização ao redor do mundo.

Em suas obras eles abordam - dentre tantos outros aspectos da condição humana violada pelo terror de estado - a presença rarefeita da poesia nos campos de trabalho forçado, onde foram confrontados diariamente com a morte e a degradação. Além da condição de testemunhas primárias das violências que abordam em seus escritos, o projeto narrativo que desenvolveram ao longo de suas trajetórias se assemelha no uso de uma linguagem seca e objetiva, na sobriedade incisiva da narração e na ausência quase total de sentimentalismo ou autocomplacência. Desenvolveram, cada um a seu modo, uma forma de narrar que escapa ao voluntarismo da confissão piedosa e assume uma tarefa ética e estética de grande envergadura, mobilizando diferentes estratégias literárias para atingir o efeito de verdade e crítica que está na base do testemunho.

1 Após a produção das peças publicitárias, no entanto, o campo voltava à rotina de fome, humilhação e extermínio dos prisioneiros. Como nos demais campos, apenas uma minoria dos prisioneiros conseguiu sobreviver depois do fim da guerra. 
A marcante presença da poesia na obra de Primo Levi, seja como tema ou como forma de expressão, não passou despercebida pelos seus intérpretes. Como o autor gostava de lembrar, o trauma de Auschwitz foi responsável direto para que ele, químico de formação, se assumisse enquanto escritor, no esforço de atender à necessidade imperativa de relatar o horror sofrido. Entretanto, antes de ser impulsionado à condição de narrador-testemunha, Levi já se aventurava pela literatura através da poesia, gênero que cultivara com maior afinco em sua juventude e que ocupa uma função importante em sua célebre trilogia de testemunho, composta por É isto um homem? (1947), A trégua (1963) e Os afogados e os sobreviventes (1986). Embora opte nessas obras pela prosa narrativa, tais livros não deixam de contar, sistematicamente, com o influxo da linguagem poética, pois:

O poema tem na obra do escritor um caráter fundante, e uma anterioridade lógica em relação à prosa. Levi insertou poemas como epígrafes em todos os seus livros de cunho testemunhal. Seu primeiro testemunho, É isto um homem?, traz, como epígrafe, o poema "Shemá", donde se extrai, também, o verso que dá título ao livro. A poesia comparece do início ao final, como contracanto à narrativa testemunhal. (MACEDO, 2019, p. 1)

Primo Levi deixou também uma produção lírica considerável, parte dela recentemente publicada em português na antologia Mil sóis (2019), com tradução e seleção de Maurício Santana Dias. Em sua produção ficcional-imaginativa, composta principalmente por contos que flertam com o fantástico e a ficção científica, a poesia também é assunto principal em algumas histórias.

No conto "A fugitiva" temos algumas pistas sobre a visão do autor a respeito da criação poética:

compor uma poesia digna de ser lida e recordada é um dom do destino: acontece a poucas pessoas, fora de toda regra e vontade, poucas vezes na vida [...] Ocorrera poucas vezes, a consciência de ter uma poesia no corpo, pronta para ser fisgada no voo e pregada no papel como uma borboleta. (LEVI, 2005, p. 447)

O conto narra a história de Pasquale, modesto funcionário de escritório que subitamente se vê tomado por uma efusão criadora e escreve um poema que julga brilhante, uma obra-prima. Porém, logo vemos que a fugitiva do título é a própria poesia, que pregará diversas peças no atordoado autor, evadindo-se tanto do papel em que foi escrita como da memória de seu criador. Descontada a ironia evidente da narrativa, vemos como Levi era fascinado pela sensação prodigiosa da criação lírica, a qual daria vida, como numa súbita explosão, ao poema. Uma variante da ideia romântica de inspiração está, sem dúvida, presente na base dessa concepção e nos ajuda a compreender como Primo Levi acreditava numa força indomável e arrebatada da poesia, em oposição ao caráter mais analítico e controlado da prosa. Talvez por isso tenha optado prioritariamente pela prosa em seus testemunhos, para escapar à obscuridade que tanto criticou em poetas de sua geração, e formular uma compreensão mais clara, lúcida e racional sobre a experiência do Lager².

No conto "O versificador", outro primor de ironia, o autor adota uma estrutura dramática, emulando um argumento teatral. Os diálogos ocorrem entre um poeta - que se encontra atordoado com a quantidade de versos de encomenda que precisa atender para suprir a sua subsistência -, sua cética secretária e um hábil vendedor que lhe apresenta uma máquina de fazer versos, capaz de substituí-lo

2 No ensaio "Dello scrivire oscuro" [Sobre o escrever obscuro], Levi critica poetas como Paul Celan e Georg Trakl pelo hermetismo de seus versos, defendendo a busca pela clareza da expressão como um esforço necessário para a reconstrução de um ideal humanista abalado pelas catástrofes do século. 
em grande parte de suas demandas profissionais. A ação principal trata da negociação em torno da compra do versificador, com a apresentação de suas funcionalidades e o teste prático de seus recursos. Todos os detalhes da negociação ocorrem em flashback, pois na abertura já somos informados que o escritor comprou a máquina e está muito satisfeito com seu uso. Por meio da ficção científica, Primo Levi critica, claro, o avanço da tecnologia, cujas máquinas aparatosas vão substituindo o humano mesmo nas atividades mais subjetivas. Vale, porém, observar que a máquina surge como alternativa genuína a um poeta que já havia perdido a inspiração, pois a maior parte de seu tempo era dedicada a escrever textos em homenagem a políticos, versos para serem lidos na inauguração de monumentos ou elegias feitas sob medida para o velório de magnatas, cada poema com um preço previamente estimulado. Dessa forma o conto critica, numa camada mais sutil, a mercantilização da literatura, via profissionalização do escritor numa lógica de mercado.

Em suas narrativas testemunhais Primo Levi também recorre à poesia em diversas situações. Se os resíduos de poesia em Auschwitz anunciavam a humanidade ceifada de algozes e prisioneiros, a carga poética que atravessa as narrativas do autor parece, por sua vez, acenar para algo que escapa ao esforço racional de compreensão humanista, trazendo à tona sentidos lacunares ou conflitantes que não poderiam ser abordados em outro plano da narração. A indagação norteadora de seu livro mais famoso, É isto um homem?, é extraída, não por acaso, do poema que funciona como uma espécie de epígrafe da obra. No poema essa questão ecoa em si mesma, enigmática, sem resposta. Já a narrativa em prosa, que acessamos na sequência, fornecerá uma resposta contundente a essa pergunta. Conforme assinala Maurício Santana Dias (DIAS, 2005, p. 14), os livros testemunhais de Levi “[p]artem de uma situação aparentemente sem saída, mas ao final terminam apontando para a vitória da liberdade humana.. Daí a importância de serem abertos por um poema, expressão de um impasse, de um abismo que a lucidez empenhada da narrativa propõe entender e, na medida do possível, superar. Ao longo do livro, a pergunta do poema que abre e nomeia $E$ isto um homem? recebe, dessa maneira,

uma resposta inequívoca: apesar de tudo, de todas as "monstruosidades", e justamente por terem atingido um ponto extremo, tanto as vítimas quanto os carrascos ali descritos continuavam participando do humano, ainda que constituíssem uma humanidade exacerbada em suas potencialidades. (DIAS, 2005, p. 15)

Nesse sentido, podemos entender as alusões à poesia na obra de Primo Levi como um contraponto - ou contracanto, se quisermos retomar o termo de Macedo (2019) - ao racionalismo humanista que orienta filosoficamente o seu olhar para as relações sociais, culturais, éticas, morais e econômicas que testemunhou em Auschwitz. À poesia corresponderia uma forma lateral, transfigurada e arrebatadora de cerzir as fraturas deixadas pela experiência incomensurável da violência sofrida, ao mesmo tempo em contiguidade e em tensão com a demanda de clareza, precisão e lucidez que seriam as marcas primordiais de seu testemunho.

Feitas essas considerações, podemos nos alongar um pouco mais no exame de "O canto de Ulisses”, um dos capítulos mais marcantes de É isto um homem?. Nele o narrador-testemunha relata uma breve pausa no trabalho brutal do campo para auxiliar Jean Samuel, companheiro de infortúnio que havia sido encarregado de buscar a enorme panela com a sopa a ser distribuída entre os prisioneiros de seu comando. Embora o peso da panela fosse bastante considerável, durante o caminho de ida eles atravessariam grande parte do campo sem nenhuma carga, o que constituía uma tarefa amena para 
os padrões do lugar. Além disso, seriam valiosos minutos sem a fiscalização coercitiva do Kapo: os dois prisioneiros poderiam conversar com alguma tranquilidade enquanto discretamente adotavam o trajeto mais longo para chegarem ao destino, ampliando ao máximo aquele breve intervalo de relativa liberdade. A certa altura da caminhada, o narrador propõe uma breve lição de italiano a Jean, que falava bem outras línguas mas afirmara nada conhecer do idioma de Levi.

Os ensinamentos são feitos por meio da leitura de um episódio d'A Divina Comédia, de Dante Alighieri, no qual o poeta narra a punição dada a Ulisses em um dos círculos do inferno. O narrador vocalizava de memória o texto original de Dante e em seguida o traduzia, improvisadamente, para o francês, explicando algumas imagens e vocábulos. A passagem constrói um complexo quadro linguístico, no qual está presente o esforço para lembrar os versos da obra máxima do cânone italiano, a angústia de ter que mediar, pela tradução, um texto familiar para uma língua estrangeira, além, é claro, do sentido inicial da cena, que é o de oferecer uma breve aula de idioma. Assim, memória, narrativa, poesia e linguagem se entrelaçam como modos de re-imersão do sujeito no domínio do humano, opondo-se ao linguajar bruto do campo e ao apagamento planejado da subjetividade dos prisioneiros engendrado pelos nazistas.

Outro aspecto que salta aos olhos na construção deste capítulo é a sua minuciosa formulação artística. Se o tratamento literário dado à matéria testemunhal é evidente ao longo de toda a trajetória de Levi, neste texto ele assume uma de suas formas mais depuradas. Desde o início o hábil trabalho estético se faz notar:

Éramos seis, raspando e pintando o interior de uma cisterna enterrada no chão; a luz do dia chegava até nós só através da portinhola. Era um trabalho de luxo, ninguém nos controlava; só que estava frio, úmido; o pó da ferrugem irritava as nossas pálpebras e nos empostava a boca e a garganta num gosto como de sangue. (LEVI, 1988, p. 160)

As primeiras frases captam a labuta diária dos prisioneiros que trabalhavam no Kommando químico, último posto que Levi ocupou no campo antes da libertação pelas tropas russas, em 1945. Os verbos no pretérito imperfeito delineiam um quadro típico, indicando que aquele trabalho se repetia exaustivamente ao longo dos dias. A fixação dessa cena cotidiana funcionará como contraste para o trabalho excepcional que será executado na sequência da narrativa, fazendo o leitor entender melhor o quão aprazíveis seriam aqueles minutos de escape da implacável rotina do campo. Além disso, a imagem do trabalho subterrâneo - sem jamais abandonar a precisão descritiva e a fidelidade documental - antecipa sugestivamente o reconhecimento e a projeção que o narrador estabelecerá com a Comédia. A “cisterna enterrada no chão", onde realizam o serviço, alude ao inferno dantesco, com sua escuridão e o gosto de sangue e morte que deixa na boca. Por ela, "a luz do dia chegava [...] só através da portinhola”, num jogo de claro-escuro que ecoará nas outras tensões que percorrem o capítulo, como memória e esquecimento, a desumanização imposta pela vida no campo e recuperada, num átimo, pela fruição da poesia, e, por fim, o choque entre o sublime do canto poético e a desolação total do Lager.

Quando a narrativa passa a abordar especificamente a lição de italiano, a linguagem acompanha o narrador em sua cada vez mais angustiada e frenética tentativa de rememorar os versos: "vem à tona algum fragmento inaproveitável", "tenho que contá-las em prosa: um sortilégio", "novamente uma lacuna, dessa vez irreparável”. O esforço hercúleo para recordar literalmente os versos do poema de 
Dante se materializa numa confissão extrema, pois é simultaneamente de uma trivialidade quase singela (para o mundo fora do campo) e de uma agudez quase hiperbólica (para o contexto dos prisioneiros de Auschwitz): "Eu renunciaria à minha ração de sopa para poder ligar 'non ne avevo alcuna' com os versos finais” (LEVI, 1988, p. 169), afirma o narrador. Renunciar à minguada ração de sopa equivalia concretamente a arriscar a própria vida, sacrificando o corpo, já fragilizado pela fome extrema, em benefício da vivência prolongada dos versos amados.

Vale a pena enfatizar que o diálogo de Primo Levi com a obra de Dante, especialmente com a Comédia, é uma tônica ao longo de sua trajetória. O embate com o poeta atravessa os seus escritos em inúmeras alusões intertextuais. A respeito dessa presença, Lucíola Freitas de Macedo afirma com precisão que Dante está para Primo Levi como Virgílio está para Dante (MACEDO, 2019, p. 2). Nesse caso, a identificação do narrador com a exortação de Ulisses aos seus companheiros, presente no trecho da Comédia evocado por Levi, instaura uma ruptura ativa com a interpretação consagrada da passagem, atualizando conscientemente o sentido clássico do poema:

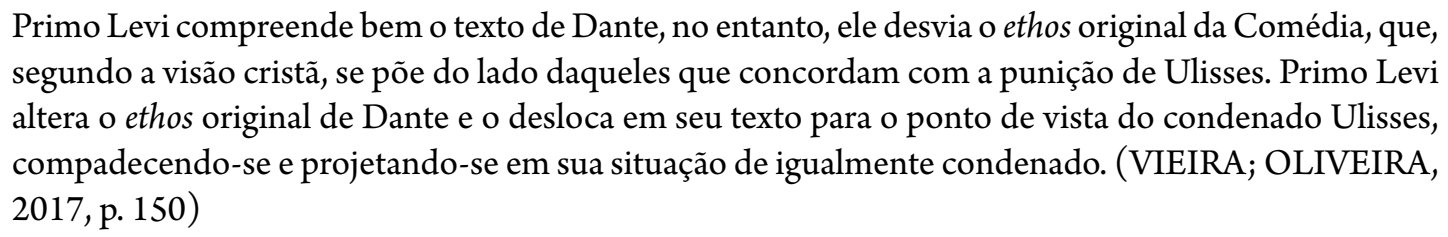

Desse modo, o processo de re-humanização através da poesia, efetivado pelo narrador nessa passagem da obra, passa também pela sensibilidade de atualizar a matéria literária de Dante, numa postura que é, certamente, de reverência ao autor mas também de liberdade para a reconstrução crítica e afetiva da obra, sob o impacto da situação de penúria que vivia. Preencher as lacunas que a violência sofrida impôs à recordação total do poema equivale, para Levi, a uma prova cabal de que ainda estava vivo, de que o horror pelo qual foi tragado não havia conseguido alcançar seu intento maior e ali, ainda que com o corpo esquelético e ferido pelos açoites, havia um homem capaz de se emocionar, lembrando da vida lá fora e de quem ele realmente era.

Em suma, observamos que em “O canto de Ulisses” a devoção à palavra poética é quase irrestrita, e sua importância torna-se evidente através do frenesi do narrador diante da cadeia de ritmos e imagens que aquele breve intervalo de caminhada fez pulsar em sua memória. O poder transformador da poesia se faz irradiar por diversas razões que a narrativa vai enlaçando. Em primeiro lugar, ela é uma impactante forma de projeção e identificação: as semelhanças com o sofrimento formalizado no poema permitem ao narrador olhar para sua situação com certo distanciamento, recebendo do poema palavras vitais que ajudam a compreender a si e ao seu redor de maneira ampliada.

Em segundo lugar, relembrar o poema o transpõe a outro espaço e tempo. O contato com a língua materna e com a rica cultura plasmada no clássico maior de seu país permite uma fugaz evasão do horror a sua volta. As imagens do poema vêm acompanhadas de memórias afetivas, como a "penumbra do crepúsculo quando eu retornava de trem para casa!”. Através da ascese estética, o sujeito se desloca do horror a sua volta: "por um momento, esqueci quem sou e onde estou" (LEVI, 1988, p. 167). Em clara oposição ao projeto nazista de apagamento de qualquer índice de subjetividade dos prisioneiros, a lembrança da poesia propicia uma religação afetiva com o mundo além do campo. 
Por fim, cabe ressaltar que o episódio incorpora um tema caro ao pensamento de Levi: o da transitividade do testemunho. Para ele, a narrativa, seja a da beleza mais pungente ou do terror mais atroz, só se efetiva no encontro com o outro. Por isso o pesadelo recorrente em Auschwitz, que ele aborda em diversos livros e entrevistas: o sobrevivente que volta para casa e não encontra ninguém para ouvir sua história, pois não se interessam ou não acreditam em seu relato. Ora, no episódio analisado há um Jean Samuel atento, esforçando-se para ouvir e entender os meandros do poema recitado pelo amigo. Jean é a personificação daquele que não vai embora, aquele que fica para ouvir o relato insuportável do outro (GAGNEBIN, 2006, p. 57). O narrador está ciente dessa premência ("Seguro Pikolo, é absolutamente necessário e urgente que escute, que compreenda") e da cumplicidade entre quem diz e quem ouve, ambos parte de um ato que só se consuma por meio desse encontro fraterno: "nós que ousamos discutir sobre essas coisas, enquanto levamos nos ombros as alças do rancho" (LEVI, 1988, p. 168).

Anos depois, ao revisitar a narrativa de "O canto de Ulisses" em seu livro de ensaios Os afogadose os sobreviventes, Levi endossa a força daquela cena como desencadeadora de uma experiência decisiva naquele momento de dor. Faz inclusive questão de repetir, literalmente, a afirmação de que "teria dado verdadeiramente pão e sopa, ou seja, sangue, para salvar do nada aquelas recordações” (LEVI, 2004, p. 119). Todavia, o tom do ensaio é menos eufórico do que aquele presente em “O canto de Ulisses”. Não encontramos mais o mesmo entusiasmo luminoso em relação ao poder salvador da poesia, embora permaneça o reconhecimento cauteloso de que mesmo no ambiente embrutecido dos campos a cultura podia "em alguns casos marginais e por curtos períodos [...] embelezar algumas horas, estabelecer uma ligação fugaz com um companheiro, manter a mente viva e sadia." (LEVI, 2004, p. 121, grifo nosso).

Mas no mesmo livro o autor assevera, numa chave mais negativa, que nenhum conhecimento, nenhuma arte, poderia jamais orientar ou compreender a vida terrível imposta nos campos. Restabelece, assim, um limite claro para o papel da arte - em especial da poesia - no contexto de Auschwitz: este limite seria dado exatamente pela incomensurabilidade da Shoah, diante da qual a arte não poderia ser mais do que um lampejo humanizador, capaz de oferecer consolo, mas nunca redenção.

No outro polo de nossa reflexão, vale, de saída, registrar que as vozes que habitam a narrativa de Varlam Chalámov jamais cederiam sequer uma migalha de pão em troca do mais extraordinário verso escrito por mãos humanas. Preso por quase vinte anos no "inferno branco" do extremo norte da Sibéria, essa "fronteira entre a vida e a morte" (CHALÁMOV, 2015, p. 91), o autor criou uma obra monumental que abarca, numa prosa áspera, as mazelas e agruras dos Gulags. O ciclo de narrativas breves que compõem os Contos de Kolimá deu visibilidade póstuma ao autor, convertendo-se num testemunho incontornável dos campos soviéticos. Chalámov também foi poeta, com parte significativa de sua produção lírica reunida nos chamados Cadernos de Kolimá, ainda sem tradução para o português, nos quais o horror inominável do universo concentracionário segue no centro de suas preocupações artísticas.

A sensibilidade poética apurada é nítida também em suas narrativas em prosa, especialmente na construção das imagens de degradação e fantasmagorias que perambulam pelos contos ${ }^{3}$. Neles encontramos inúmeras alusões a poetas e poemas: Púchkin, Blok, Iessiênin e Mandelstam são os

3 No prefácio aos Contos de Kolimá, Irina Sirotínskaia afirma que "a natureza do talento de Chalámov é eminentemente lírica" (CHALÁMOV, 2015, p. 15). 
mais recorrentes, e perfilam-se com diversas finalidades intertextuais no interior de seus relatos. Contudo, sua evocação da poesia é sistematicamente marcada pelo desencanto e o ceticismo, com ênfase na incongruência entre a expressão artística e a hostilidade do meio em que ela tortuosamente se manifestava.

No segundo volume da tradução brasileira de sua obra, intitulado $A$ margem esquerda, temos um exemplo de como Varlam Chalámov encarava a emergência da poesia nos Gulags. No conto "Não convertido", o narrador encontra-se na fase final do processo de seleção para um posto de enfermeiro do campo, cargo que lhe daria vantagens importantes na luta pela sobrevivência, especialmente por ser um trabalho realizado em espaço fechado, parcialmente protegido do frio congelante da região. Nina Semiônovna era a médica responsável pelo treinamento e recrutamento dos candidatos habilitados ao posto e, no conto, mantém uma relação de proximidade com o narrador. A certa altura ela lhe empresta um livro de poesia de Aleksandr Blok e pede-lhe para ler em voz alta dois poemas. Eram poemas outrora muito familiares ao prisioneiro, como ele mesmo observa. Antes da prisão ele os sabia de memória, por isso, com o incentivo de Semiônovna, tenta recitá-los sem olhar no livro. Mas, assim como em Primo Levi, o véu do esquecimento obstrui a fluência da vocalização, revelando um hiato entre o sujeito do passado - livre e apaixonado por aqueles versos - e o do presente - cativo que sente uma ligação fraturada com aquela memória de leitura. Ao contrário do afinco em reconstituir as recordações que o ligam ao poema e à vida fora do campo, que vimos no autor italiano, em Chalámov o esquecimento dos versos é encarado com frieza, ou mesmo com certo alívio:

Comecei a recitar, mas imediatamente esqueci as linhas. A memória se negava a "entregar" os versos. Eu chegara ao hospital vindo de um mundo que conseguia passar sem versos. Havia dias em minha vida, e não eram poucos, em que eu não conseguia lembrar e não queria lembrar de nenhum poema. Eu me alegrava com isso, como se tivesse me livrado de um fardo desnecessário - inútil em minha luta nos andares inferiores da vida, nos porões da vida, na fossa da vida. Ali, a poesia só me atrapalhava. (CHALÁMOV, 2016, p. 99).

Vale observar que, assim como ocorreu com Primo Levi, a possibilidade de entrar em contato direto com a poesia se dá no momento em que o personagem deixa os trabalhos mais extremos, assumindo um cargo de perfil especializado. É importante notar que a fresta para acessar a poesia ocorre somente quando Chalámov está no hospital e Levi no comando químico, demarcando com clareza que nos níveis mais extremos da experiência dos campos - aqueles nos quais se encontrava a esmagadora maioria das vítimas - o acesso à poesia era ainda mais inviável. Assim, o contato não deixa de ser uma espécie de privilégio dentro da dinâmica do universo concentracionário, o que traz uma outra vertente de leitura: a do sentimento de culpa ao se entregar ao prazer da fruição poética.

Em Chalámov, a beleza disponível nos versos de Blok é recebida com enfado, como um obstáculo para manter a postura dura e inflexível que julgava a única conveniente na luta pela sobrevivência. Ele vê este reencontro como "um fardo desnecessário" e "inútil”. Interessante, porém, que na sequência do conto o narrador afirma que naquele mesmo dia: "li e reli Blok com avidez a noite toda, o plantão inteiro" (CHALÁMOV, 2016, p. 99). A contradição assinala mais uma vez o paradoxo da poesia em meio ao horror: inutilidade e urgência, necessidade e impossibilidade.

O desprezo ambíguo pela poesia é retomado com variações ao longo do livro. O narrador menciona diversas personagens que encontravam na leitura um alimento vital, aos quais ele se refere com um 
misto de admiração e desprezo. Além de Nina Semiônovna, que reage com profunda emoção quando os versos de Blók são recitados, no conto “Esperanto" lemos sobre a ação da Brigada Cultural do Campo, que frequentemente recrutava artistas amadores para se apresentarem aos demais prisioneiros. Diante do entusiasmo dos artistas, o narrador observa: "Tive inveja da felicidade do barão - podia distrair-se, fugir, esconder-se, desaparecer na poesia. Eu não conseguia fazer isso.” (CHALÁMOV, 2016, p. 218).

A percepção negativa da poesia parece ligada a uma tese bastante cara ao autor e que é apresentada principalmente no primeiro volume dos Contos de Kolimá. O lugar inóspito em que foram obrigados a viver e conviver geraria um perfil humano mutilado, obrigado a se adaptar a uma dinâmica de sobrevivência a todo custo. Os que não se despojavam rapidamente de qualquer vestígio de inclinação intelectual ou humanista eram os primeiros a perecer. A violência, a fome e o frio destruíam tanto o corpo como a alma, que "congelava inteira, encolhia-se e talvez ficasse assim para sempre" (CHALÁMOV, 2015, p. 40). Para Chalámov, o intelectual deveria se livrar rapidamente das demandas do espírito e confiar no instinto, rompendo com princípios cultivados no mundo para além do campo.

Neste ponto, ele também vai na direção oposta à de Primo Levi. Embora este concordasse que "o homem culto estava no Lager em situação muito pior que o inculto" (LEVI, p. 113), devido à frequente falta de vigor físico e habilidade para o trabalho braçal, Levi via a condição do intelectual como ambivalente. O intelectual em Auschwitz, segundo ele, igualmente gozava de mínimas vantagens, como o domínio de outras línguas, fundamentais para a sobrevivência na Babel dos campos, e, mais para o fim da guerra, a possibilidade de ocupar cargos especializados, o que conferia vantagem estratégica na luta pela sobrevivência.

Chalámov, por seu turno, acreditava que a superação da morte nos campos estaria ligada fundamentalmente à "essência do grandioso instinto de sobrevivência, qualidade dada ao homem em alto grau" (CHALÁMOV, 2015, p. 57). Essa força seria, no homem, superior a todos os animais e, quanto mais o indivíduo se entregasse a esse instinto irrefreável, afastando-se de quimeras morais, poéticas ou filosóficas, mais apto ele estaria a permanecer vivo. Nessa chave cruamente materialista é que, segundo ele, se destacaria o humano, inclusive em relação aos cavalos, pois estes, mesmo com sua robustez natural, morriam mais facilmente de frio, fome ou mesmo de desespero, enquanto uma parte significativa dos prisioneiros se agarrava ao menor fio de sobrevivência com uma bestial e decidida resistência, conseguindo "colocar o princípio espiritual a serviço do seu princípio físico" (CHALÁMOV, 2015, p. 57).

Portanto, a prosa seca e objetiva de Chalámov revela uma visão de mundo visceralmente desencantada, espelhando em sua linguagem a aspereza e a miséria que busca representar. Nisso difere bastante do estilo, também contido e objetivo, de Primo Levi. Enquanto naquele (Chalámov) a frieza e o pessimismo são pulsantes, no autor italiano a objetividade busca a precisão analítica, num trabalho testemunhal que almeja "fornecer documentos para um sereno estudo de certos aspectos da alma humana” (LEVI, 1988, p. 7), como afirma no prefácio de É isto um homem?. Em Chalámov o que vemos é uma postura desconfiada, quando não incrédula, a respeito dos valores humanistas liberais (memória, cultura, liberdade...), estando a sua visão sobre a poesia no campo articulada a uma postura ética e filosófica mais negativa.

"Xerez" aborda de forma profunda e estarrecedora o impasse da poesia nos gélidos campos onde cumpriu a maior parte de sua pena. Não por acaso, esse conto ocupa posição de destaque no 
conjunto de sua obra, tanto pela sua narrativa impactante quanto pelas particularidades formais que o notabilizam em relação ao conjunto. No Brasil ele foi publicado também na Nova Antologia do conto russo (1792-1998), outro indício de que se trata de um dos textos mais consagrados de Chalámov, o que coloca a reflexão poética no centro de sua obra.

Narra-se em "Xerez" a lenta agonia de um poeta. O autor deixa várias evidências de que se trata de Óssip Mandelstam - importante poeta russo de fato morto nos campos stalinistas - mas sem nomear o personagem, chamado genericamente de "poeta", o que permite ao conto atingir um sentido amplificado em relação ao seu tema principal. A primeira frase já assinala a presença da morte e sua vagarosa, mas implacável, investida sobre o personagem moribundo: "O poeta estava morrendo" (CHALÁMOV, 2015, p. 108). A tradução adota o gerúndio para captar o duelo longo entre o sujeito e a morte, iniciado num momento anterior ao da enunciação. A repetição dessa ideia, ora com termos muito próximos ao da frase de abertura, ora com variações, amplifica a sensação de circularidade das investidas da morte sobre o personagem que agoniza, alternando momentos de consciência, quase de clarividência, com momentos de vazio: "O poeta estava morrendo há tanto tempo que não entendia mais que estava morrendo” (p. 108), “A vida entrava e saia, e ele morria” (p. 109), "O morto de novo se tornava vivo” (p. 109), "A vida entrava sozinha, como um déspota” (p. 111).

A posição do narrador é bastante inusual nas narrativas de Chalámov e na literatura de testemunho como um todo. Adota-se um típico narrador onisciente, que penetra nos pensamentos íntimos do poeta e descreve seus inconstantes estímulos, as recordações que lhe tomam de assalto em meio à agonia, seus temores e inquietações, revelados como em um pesadelo. O uso do discurso indireto livre também é explorado, com o narrador revelando ideias que o poeta, emudecido, não pode expor devido ao seu estado físico. Ao silêncio incomunicável do poeta moribundo contrapõe-se a prosa dura, mas solidária, do narrador que penetra, como se fosse um duplo da morte, em seus pensamentos tumultuosos.

Dentre os fragmentários devaneios do poeta, um deles nos interessa especialmente nessa abordagem. Em meio à derrocada final de sua existência, ele pensa um poema. $O$ fato indelével de que aquele poema não pode ser escrito, nem sequer oralizado, dadas as condições do poeta e do meio à sua volta, não o torna menos importante, ao contrário, parece constituir uma realização superior:

Ela [a vida] entrava em seu corpo, em seu cérebro, entrava como versos, como inspiração. E o significado dessa palavra revelou-se a ele pela primeira vez, em toda a sua plenitude. Os versos eram aquela força vitalizadora, pela qual ele vivia. Exatamente assim, ele não vivia graças aos versos, ele vivia por versos. (CHALÁMOV, 2015, p. 111)

A presença intermitente da morte e o transe criativo que toca o poeta em seus instantes finais contrastam tanto com a hostilidade absoluta do ambiente no qual se encontra quanto com o sentido do próprio poema, cuja circunstância de "realização" impede o encontro com qualquer leitor, pois está destinado a perecer sem acessar o mundo. Contudo, o narrador afirma:

E daí se não estavam anotados? Anotar, publicar - tudo isso é a vaidade das vaidades. Tudo aquilo que nasce de modo interesseiro não é o que há de melhor. O melhor é aquilo que não se anota, que se compõe e desaparece, desmancha sem rastros, e apenas o prazer criador que ele sente e que não se confunde com mais nada demonstra que a poesia foi criada, que o maravilhoso foi criado. (CHALÁMOV, 2015, p. 112) 
O trecho rasura a comunicabilidade da poesia, que dependeria de um leitor atento para se efetivar, e indica um absoluto criador, uma esfera na qual a cadência do ritmo e a cadeia sugestiva das rimas bastariam em si mesmas, como num transe. Há, por certo, "algo de ingênuo, de infantil” e mesmo de incompreensível em "morrer como poeta" (p. 112) mas tal destino, no pandemônio de horrores do campo, traz algo de terrível e suave ao mesmo tempo. O narrador, mesmo onisciente, não cita nenhuma passagem deste poema, como a respeitar, ou denunciar, o seu espaço sombrio no esquecimento imposto pelo horror.

Se o conto terminasse com esse quadro arrebatador do poeta criando em meio aos últimos suspiros, seríamos forçados a reconsiderar grande parte das afirmações sobre a concepção de poesia em meio à catástrofe que tecemos a partir de outros fragmentos de Chalámov. Contudo, neste conto enigmático e terrível, "viver por versos" será confrontado com uma morte bem mais prosaica e trivial. Assim, se o centro da narrativa flerta com o sublime, a cena da morte, que ocupa os seus últimos parágrafos, decairá subitamente ao grotesco para tratar do último gesto do poeta: um esforço sobrehumano para comer um pedaço de pão:

Mas, quando lhe enfiaram nas mãos a ração diária, ele a pegou com os dedos exangues e apertou o pão contra a boca. Ele mordia o pão com os dentes de escorbuto, as gengivas sangravam, os dentes bambeavam, mas ele não sentia dor. Apertava o pão contra a boca com todas as forças, enfiava o pão na boca, chupava, rasgava e roía... [...] Ao anoitecer, ele morreu. (CHALÁMOV, p. 114-115)

Após flertar com a altivez da paz espiritual, enquanto, tomado de inspiração, compunha versos em sua mente inconstante, o poeta passa seus últimos momentos entregue ao instinto mais primitivo de devorar vorazmente o pão, ciente de que poderia ser o último gesto de sua vida. É perturbador o contraste entre a mente inspirada e o corpo esfarrapado, brutalmente devorado pelo frio, a fome, a sujeira, o escorbuto, tornando o simples ato de comer um tormento. O poema luminoso, mas natimorto, que concebeu no transe criativo permanecerá ignoto, enquanto a fúria com que come o pão é concreta, visceral.

Ao falar da sina imposta aos poetas russos do século XX, Roman Jakobson assinala, no importante ensaio A geração que esbanjou seus poetas, que:

a voz e o pathos falharam, a reserva aberta de emoções, alegria e aflição, sarcasmo e entusiasmo, foi consumida, e eis que a convulsão dessa geração sem sucessores aparece não como um destino particular, mas como o rosto do nosso tempo, uma sufocação da história. (JAKOBSON, 2006, p. 52)

A homenagem que "Xerez" faz a Óssip Mandelstam parece cumprir o propósito de condensar em sua trágica história o réquiem de uma geração de poetas esmagados tragicamente pela história terrificante do século, ao mesmo tempo em que gera uma figuração extrema da poesia em meio ao horror. Da catástrofe emerge um poema peculiar, que nasce vizinho à própria morte, se não como uma extensão dela; poema que o campo simultaneamente estimula e apaga.

Por fim, o desfecho do conto não poderia ser mais irônico: após sua morte, os companheiros conseguem, por dois dias, estender o braço do cadáver durante a distribuição e ficar com a sua ração diária de alimento. O narrador conclui na frase que encerra a narrativa: "Quer dizer, ele morreu antes da data de sua morte - um detalhe bem importante para os seus futuros biógrafos” (CHALÁMOV, 
2015, p. 115). Ou seja, a narrativa retoma o âmbito da poesia, expondo o risco de todo aquele horror ser reduzido a um pormenor de datas na construção de homenagens futuras ao poeta.

Em suma, "Xerez" aborda outro âmbito da poesia nos campos da morte. Não o da leitura e fruição, como nos casos comentados anteriormente, mas o do ímpeto criador que, em meio a uma situação-limite, se mantém aceso como uma necessidade elementar. Aos que mantiveram vivo esse ímpeto, o conto se dirige com respeito e até mesmo com admiração, embora faça questão de evidenciar sua impotência diante de uma realidade avassaladora. $\mathrm{O}$ sublime da inspiração poética reluz, fugaz, em meio às trevas, para em seguida voltar a ser devorado pelas contingências mais elementares que o rodeiam. Os vizinhos de infortúnio jamais conhecerão o poema inefável que brotou do espírito do poeta em agonia, mas em sua audácia profana, utilizam seu corpo morto, como uma marionete, para conseguir mais uma ração que poderá significar a sobrevivência. $O$ contraste é brutal e perturbador, amplificado porque a narrativa não deixa caminhos óbvios de interpretação para o relato.

Finalmente, o exame comparativo das menções de Primo Levi e Varlam Chálamov a respeito do (não)lugar da poesia nas indústrias modernas da morte onde foram aprisionados pode, num primeiro olhar, situar duas visões opostas a respeito da expressão poética. Levi celebrando o papel humanizador da arte, seja como comunicação, como reafirmação da sensibilidade, da identidade e do prazer. A memória cintilante da poesia seria, em sua obra, capaz de trazer uma fresta de beleza e um mínimo alento em meio à dor. Enquanto isso, Chalámov evidenciaria o ceticismo em relação ao poder libertador da poesia num espaço em que os vestígios de humanidade estariam de tal forma mutilados que a recaída na fruição estética revelaria uma futilidade, uma fraqueza. Mesmo que muitos dos seus personagens e alguns narradores que habitam seu universo narrativo, situado no inferno gélido de Kolimá, não estejam imunes ao deleite propiciado pela poesia, a nota geral é de profunda desconfiança a respeito do real sentido dessa vivência.

Não obstante essa nuance fundamental que distancia as duas perspectivas, em ambos é possível observar um movimento crítico mais complexo, no qual os limites de suas próprias convicções a respeito da relação entre poesia e catástrofe são expostos e matizados, estabelecendo algum tipo de tensão que retoma um paradoxo que está na base tanto da expressão poética quanto do testemunho.

O conjunto das narrativas que compõem $E$ isto um homem? expõe sistematicamente a violência e o horror, demarcando a vivência poética pungente em "O canto de Ulisses" num plano mais geral - nada ingênuo ou triunfante - da barbárie de Auschwitz. Enquanto nos Contos de Kolimá, Chalámov, mesmo ao negar qualquer função transgressora ou consoladora à poesia, retorna a ela sistematicamente, seja em intertextos ou em narrativas metalinguísticas. Assim, a negação tem em sua base uma preocupação ética e estética fundamental, jamais confundida com a indiferença.

Refletir sobre a poesia em meio à catástrofe mostrou-se, para estes autores, uma tarefa primordial ao longo de suas obras. A poesia do testemunho e o testemunho da poesia confluem nestes dois pensadores com uma forte carga dramática, expondo um impasse que está na base de qualquer empreendimento de compreensão da virulência dos estados totalitários e de suas marcas na produção artística que a eles sobreviverá, de algum modo. 


\section{REFERÊNCIAS}

ADORNO, T. Prismas - Crítica cultural e sociedade. São Paulo: Ática, 1998.

BOSI, Ecléa. O tempo vivo da memória: ensaios de psicologia social. São Paulo: Ateliê Editorial, 2004.

CHALÁMOV, Varlam. Contos de Kolimá. Trad. Denise Sales e Elena Vasilevich. São Paulo: Editora 34, 2015.

CHALÁMOV, Varlam. A margem esquerda. Trad. Cecília Rosas. São Paulo: Editora 34, 2016.

GAGNEBIN, Jeanne Marie. Palavras para Hurbinek. In: NESTROVISKI, A; SELIGMANN-SILVA, M. Catástrofe e Representação. São Paulo: Escuta, 2000.

GAGNEBIN, Jeanne Marie. Lembrar Escrever Esquecer. São Paulo: Editora 34, 2006.

GOMIDE, Bruno Barretto (org). Nova antologia do conto russo (1792-1998). Trad. Arlete Cavalieri et al. São Paulo: Editora 34, 2011.

GULLAR, Ferreira. “Homem Comum”. In: Toda Poesia. Rio de Janeiro, José Olympio, 2010.

JAKOBSON, Roman. A geração que esbanjou seus poetas. Trad. Sonia Regina Gonçalves. São Paulo: Cosac Naify, 2006.

LEVI, Primo. É isto um homem? Trad. Luigi Del Re. Rio de Janeiro: Rocco, 1988.

LEVI, Primo. Os afogados e os sobreviventes. trad. Luiz Sérgio Henriques. São Paulo: Paz e Terra, 2004.

LEVI, Primo. Mil sóis: poemas escolhidos. Trad. Maurício Santana Dias. São Paulo: Todavia, 2019.

LEVI, Primo. 71 contos de Primo Levi. Trad. Maurício Santana Dias. São Paulo: Cia. das Letras, 2005.

MACEDO, Lucíola Freitas de. Primo Levi: sonho, poesia e política. Arquivo Maaravi. Belo Horizonte, v. 13, n. 25, p. 1-10, 2019

SELIGMANN-SILVA, Márcio. Arte, dor e Kátharsis ou Variações sobre a arte de pintar o grito. Alea, v. 5, n. 1, p. 29-46, 2003.

VECCHI, Roberto. Restos indissolúveis da crueldade: considerações sobre violência, mal e escrita literária. ContraCorrente: Revista do Programa de Pós-Graduação Interdisciplinar em Ciências Humanas, [S.1.], n. 2, p. 173-186, maio 2017. Disponível em: <http://periodicos.uea.edu.br/index.php/contracorrente/article/ view/475>. Acesso em: 07 dez. 2020. 